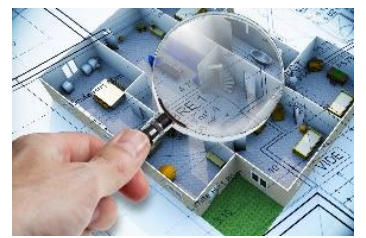

\title{
Emergency use of a floating bridge within a large urban conurbation
}

\author{
Ryszard CHMIELEWSKI ${ }^{1}$ (ORCID ID: 0000-0001-5662-9180) \\ Mieczyslaw PIECHOTA ${ }^{1}$ (ORCID ID: 0000-0002-0094-9246) \\ Bartosz BAWIEC ${ }^{1}$ (ORCID ID: 0000-0002-8345-1952) \\ ${ }^{1}$ Military Univ. of Technology, Dept. of Military Engineering and Military Infrastructure, 2 Kaliski Str., 00-908 Warsaw, Poland \\ corresponding author: ryszard.chmielewski@wat.edu.pl
}

\begin{abstract}
The article presents an analysis of the use of a floating bridge within a large urban conurbation in an emergency situation. The analysis is associated with a failure of the system transferring sewage from left-bank Warsaw to the 'Czajka' treatment plant located on the right-bank of the Vistula River. It includes checking the load bearing capacity of a typical floating bridge structure constructed using the PP-64 pontoon system supporting two pipelines transporting sewage across a wide water obstacle.
\end{abstract}

Keywords: 'Czajka' treatment plant; floating bridge; PP-64 pontoon system.

Access to the content of the article is only on the bases of the Creative Commons licence CC BY-NC-ND 4.0

Please, quote this article as follows:

Chmielewski et al., Emergency use of a floating bridge within a large urban conurbation, Engineering Expert, p. 24-34, No. 1, 2020, DOI: 10.37105/enex.2020.1.1.04

\section{Introduction}

The article presents an analysis of using a PP-64 pontoon system floating bridge, part of the assets of the Polish Armed Forces, in an emergency associated with a failure of the system transferring sewage from left-bank Warsaw to the 'Czajka' treatment plant located on the right-bank of the Vistula River. Initially, on 27 August 2019 the main transmission pipe suffered a breakdown and wastewater was re-routed to a backup transmission pipe. Unfortunately, within 24 hours that transmission pipe also broke down, as a result of which sewage was being dumped into the Vistula River. In order to minimise the consequences of polluting the river, wastewater ozone treatment began. However, approximately 260 thousand cubic metres of sewage was discharged in a day. Such a situation required a temporary sewage transfer system to be put in place. The government emergency team made a decision to build a bridge that would be used as an emergency system to transport sewage across the Vistula River. Fig. 1 below depicts the sewage discharge site. A steel collector tank constructed out of steel sheet piles can also be seen, together with pumps in place to receive wastewater.

A PP-64 pontoon set, operated by the Polish Armed Forces, was chosen for the temporary bridge [8]. The system designed to establish bridge and ferry crossings is operated by army engineering units. The equipment can be used to build single lane, double lane or mixed configuration pontoon bridges. It facilitates crossings of natural and artificial water obstacles with surface current speeds of up to 2.5 $\mathrm{m} / \mathrm{s}$. Single and mixed lanes (type A and B) deliver a payload capacity of $40 \mathrm{Mg}$, type C and D lanes are rated at $50 \mathrm{Mg}$, and a double lane has a capacity of $80 \mathrm{Mg}$ [8]. 


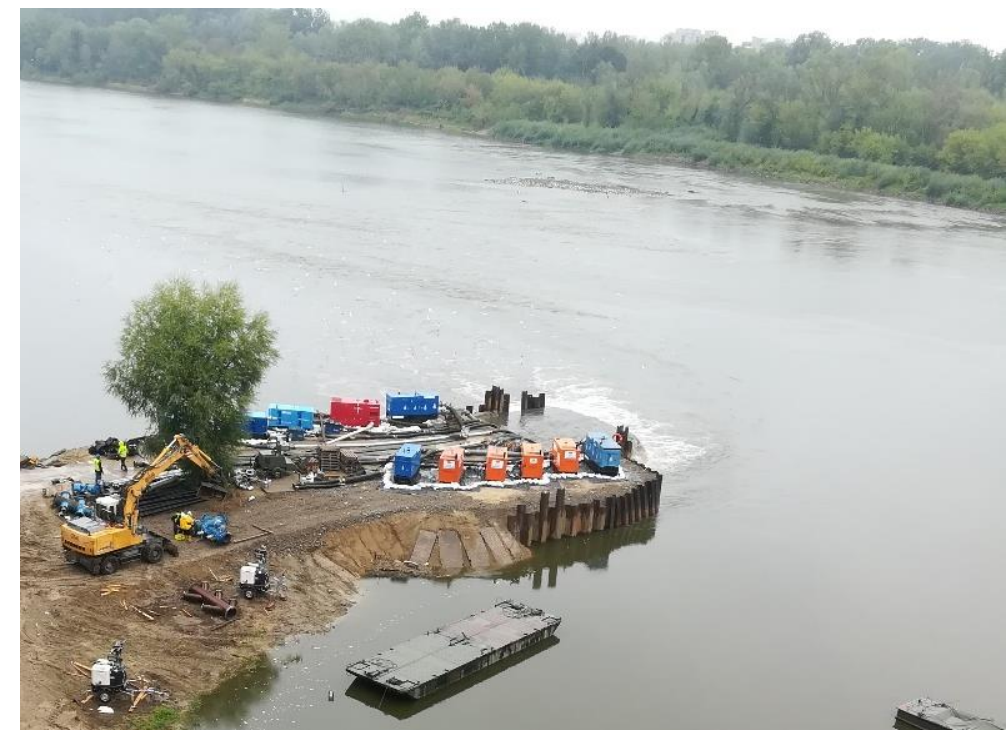

Fig. 1. Sewage discharge site on the Vistula River [own photograph].

Floating bridges are most often used to facilitate the movement of troops, although they are increasingly used in emergency situations to establish crossings. These crossings take the load of columns comprised of moving vehicles and are designed for such purpose [1]. The advantage of bridges of this type over collapsible bridges lies in the speed of construction of a crossing and in the fact that they do not require a support system. Undoubtedly, the fact that they have to be disconnected to let vessels pass or when there is a danger of ice floes is a disadvantage. It is worth noting that until the construction of the crossing in question took place, pontoon bridges were not used to support pipelines. The study [5] analyses the possibility of using the PP-64 system to construct a pipeline to secure the supply of liquid materials, although this solution was not put into practice. In conjunction with the above, such unusual use of a pontoon bridge presented challenges in terms of how the bridge crossing was constructed and how it was maintained.

\section{Pontoon bridge structural system}

\subsection{Determining the bridge set}

Determining the bridge set aims to identify the number of pontoon units forming part of the bridge and to ascertain whether the conditions at the selected site facilitate connecting the bridge to the shore. This is determined on the basis of an engineering survey, i.e. the width and depth of the river as well as the speed of its current. Data on water level fluctuations during the bridge building phase and the period when the bridge is in use are essential. Such a survey for the crossing in question was already carried out three days after the failure by soldiers designated to construct the bridge. In determining the bridge set, conditions that the crossing was to satisfy were taken into account:

- an appropriate length of the floating section was adopted to reflect the width of the river, assuming water depth of not less than $0.4 \mathrm{~m}$ below the ends,

- to calculate the number of units, the width of a floating unit was assumed to be $3.7 \mathrm{~m}$ and shore units were assumed to be $4.0 \mathrm{~m}$ long,

- a $1 \%$ river width measurement error was assumed.

According to the engineering survey, the width of the river at the crossing site was approximately $241 \mathrm{~m}$, while the current speed was measured at $0.7 \mathrm{~m} / \mathrm{s}$.

A PP-64 system set comprises 48 floating units mounted on Star 266 AP-64 vehicles, 6 complete shore units on STAR 266 BP-64 vehicles, $6 \mathrm{KH}-200$ bridging boats, and 6 dropside trucks for towing boats carrying ramps and other equipment. $\mathrm{A}$ ' $\mathrm{C}$ ' type lane was used to perform set calculations. In a bridge of this type, every third bridge segment is made up of two floating units. Fig. 2a shows a shore 
section of the bridge, whilst a river section is shown in Fig. $2 \mathrm{~b}$ a shore section comprises three floating units and 1 shore unit; it is $11.4 \mathrm{~m}$ long $(2 \times 3.7 \mathrm{~m}+4.0 \mathrm{~m})$. A river section comprises 4 floating units; it is $11.1 \mathrm{~m}$ long $(3 \times 3.7 \mathrm{~m})$.
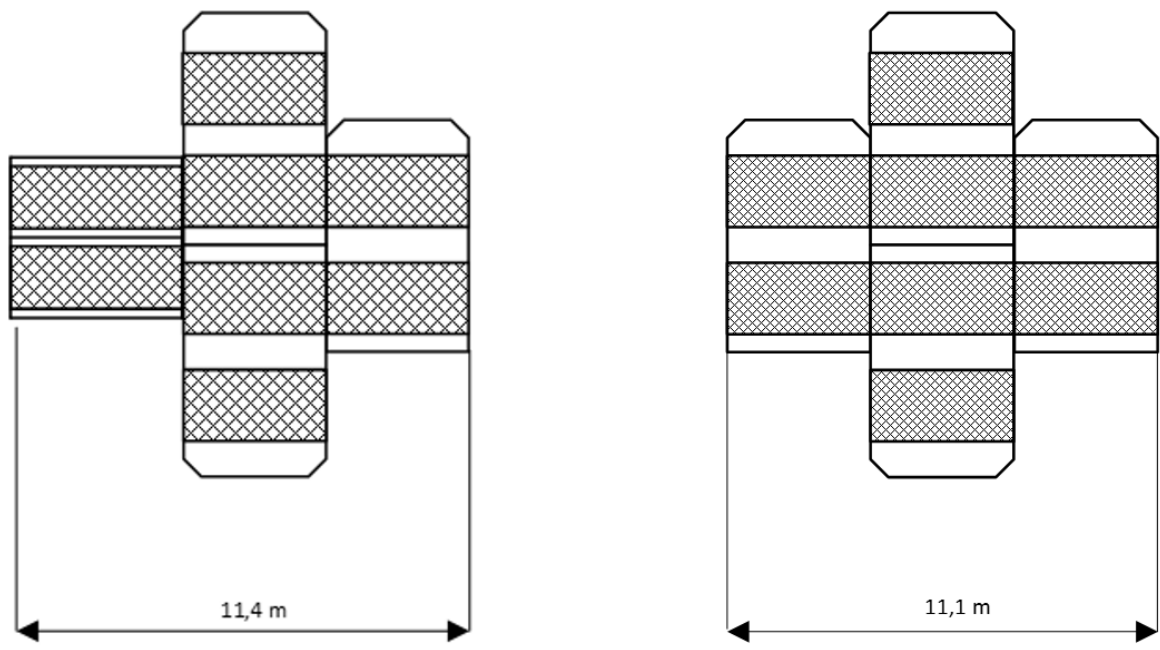

Fig. 2. ' $C$ ' type floating bridge elements: a) shore section, b) river section.

A water obstacle spanning $241.0 \mathrm{~m}$ requires two shore sections and twenty river sections. The total length of the floating bridge was $244.8 \mathrm{~m}$. 86 floating units and 2 shore units were used. Fig. 3 depicts a diagram of half of the bridge, a fragment of the assembled bridge is shown in Fig. 4.

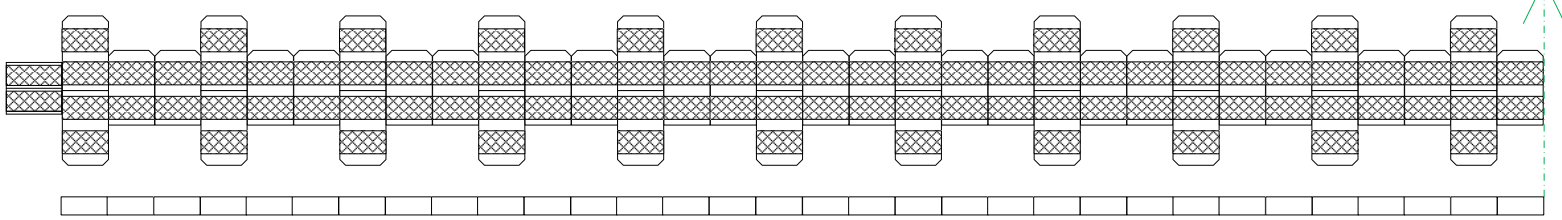

Fig. 3. Diagrammatic representation of half of a ' $C$ ' type floating bridge.

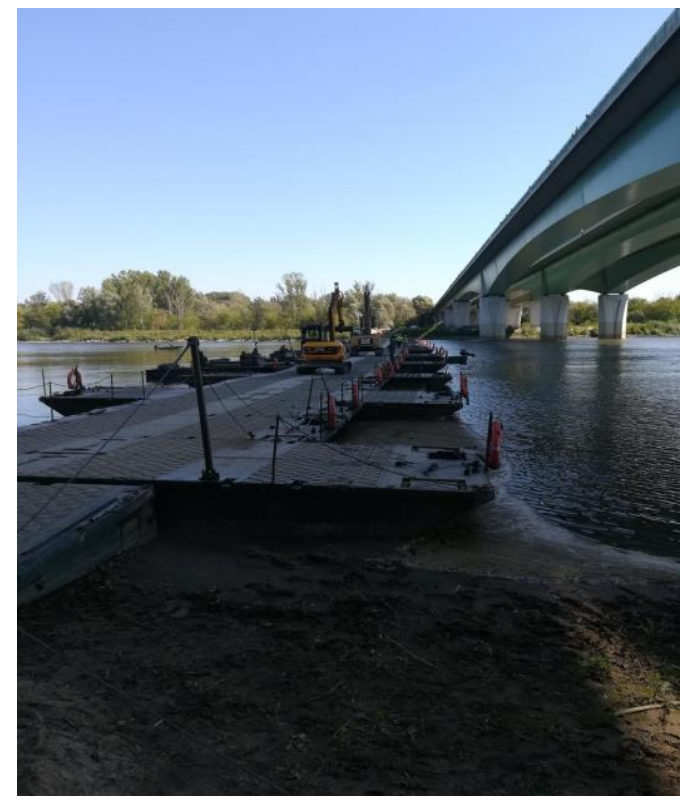

Fig. 4. A fragment of the assembled bridge [own photograph] 


\subsection{Technical assessment of the adopted structural system}

The technical assessment aimed to verify the load bearing capacity of the adopted structural system (type $\mathrm{C}$ floating bridge) supporting two sewage discharge pipelines. The payload capacity for a single vehicle is $50 \mathrm{Mg}$. A basic bridge lane section of this type comprises four units (one double and two single) with a payload capacity for a single unit of $5 \mathrm{Mg}$. A basic unit is $11.1 \mathrm{~m}$ long and has a payload capacity of $20 \mathrm{Mg}$.

A $1 \mathrm{~m}$ length of an empty pipe weighed $0.263 \mathrm{Mg}$, had an internal diameter of $0.804 \mathrm{~m}$ and a cross-sectional area of $0.51 \mathrm{~m}^{2}$. The maximum volumetric weight of sewage stands at $1.20 \mathrm{Mg}$ per cubic metre, and hence the payload per one full pipe is $0.609 \mathrm{Mg}$ per metre of length. The payload from one pipe is $0.872 \mathrm{Mg}$ per metre of length and for a basic section this translates into $19.36 \mathrm{Mg}$ (two pipelines with sewage).

The above calculations show that the PP-64 pontoon system bridge in the $\mathrm{C}$ type lane arrangement will support payloads under assumed normal use, while the estimated remaining $3.2 \%$ capacity reserve will provide support for the pipelines on the bridge [4]. This reserve was sufficient for $0.212 \mathrm{Mg}$ of support structure for two pipelines over the width of one pontoon unit $(3.7 \mathrm{~m})$.

Due to the fact that the load bearing structure of the pontoon system was designed for transporting loads along its axis, it was necessary for the sewage to be fed onto the bridge perpendicularly to the shore. This was particularly significant due to the durability and safety of attachments on pontoon units which may be the weakest link of the PP-64 system.

An option to compensate the pipelines was also provided, which was required due to river water level fluctuations and changes in external temperature.

\section{Lining-up and connecting pipelines}

\subsection{Laying pipelines on the bridge}

The next stage entailed an analysis and selection of a method to lay the pipelines on the bridge. As there was an urgent need to start pumping wastewater quickly, the pipeline contractor originally proposed a method involving laying one pipeline and then the other alongside the already laid pipes (Fig. 5).

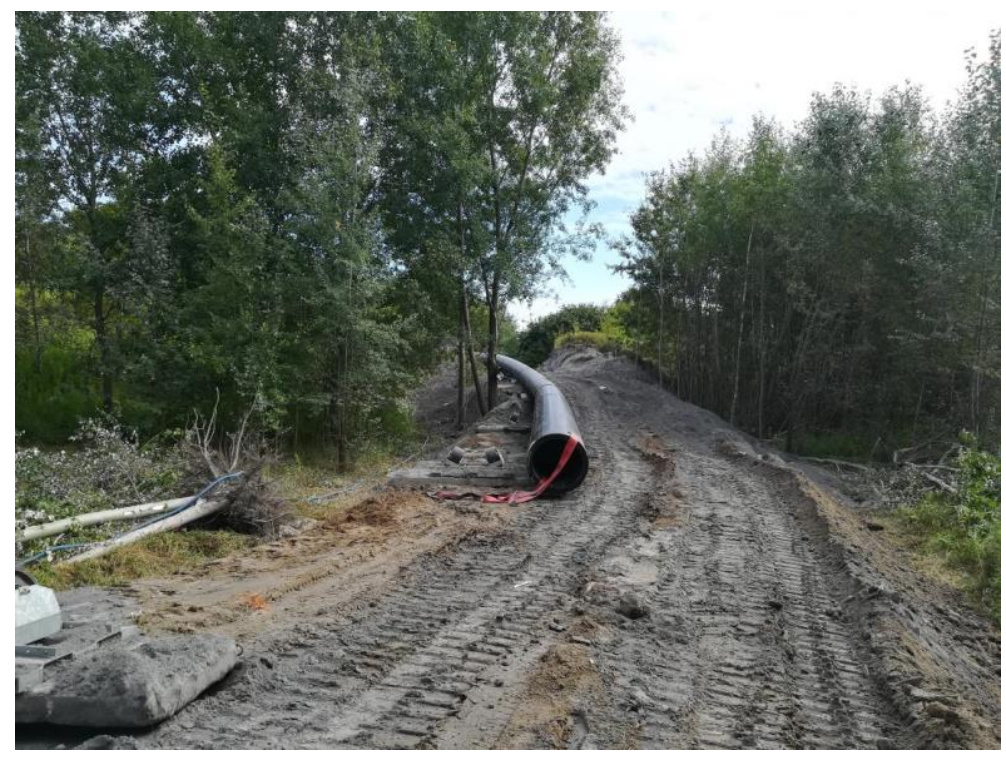

Fig. 5. Lining-up a single pipeline on the shore [own photograph]

Laying the pipelines using this method was not feasible on account of the bridge use and organisational limitation. The first problem was the highly eccentric load, which required anchor 
tensioners to be adjusted, posing a direct risk to the stability of the crossing. The second problem was associated with the lack of space for machinery laying the second pipeline over the crossing. Another problem was discovered on the shore while bringing the pipeline to the bridge crossing: heavy equipment pulling pipes would rise and temporarily transfer loads with only part of its tracks. This was unacceptable. In conjunction with the above, army representatives outlined a concept entailing laying two pipelines simultaneously (Fig. 6).

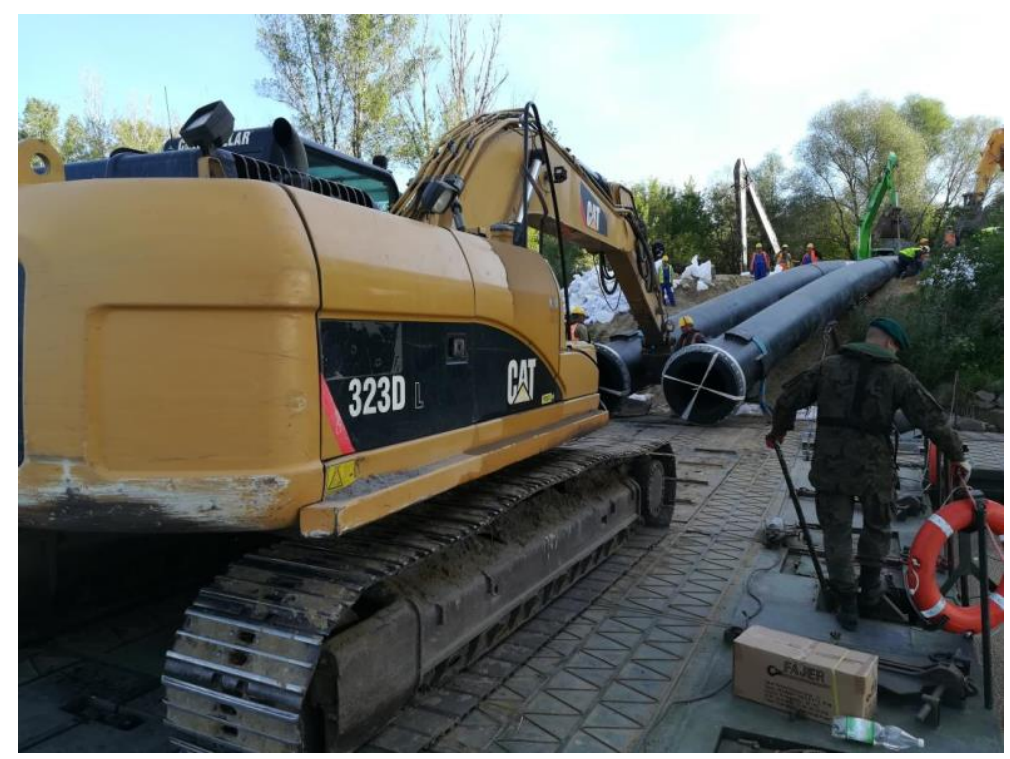

Fig. 6. Laying two pipelines simultaneously [own photograph].

Laying pipes onto the bridge was done in 'steps'. A heavy excavator (30 Mg) moving along the bridge axis lifted and then inserted the pipes in approximately $5.0 \mathrm{~m}$ sections. At the same time, an excavator on the shore would push the pipelines together. Special rollers mounted on every double unit were used to lay the pipelines on the bridge (Fig. 7).

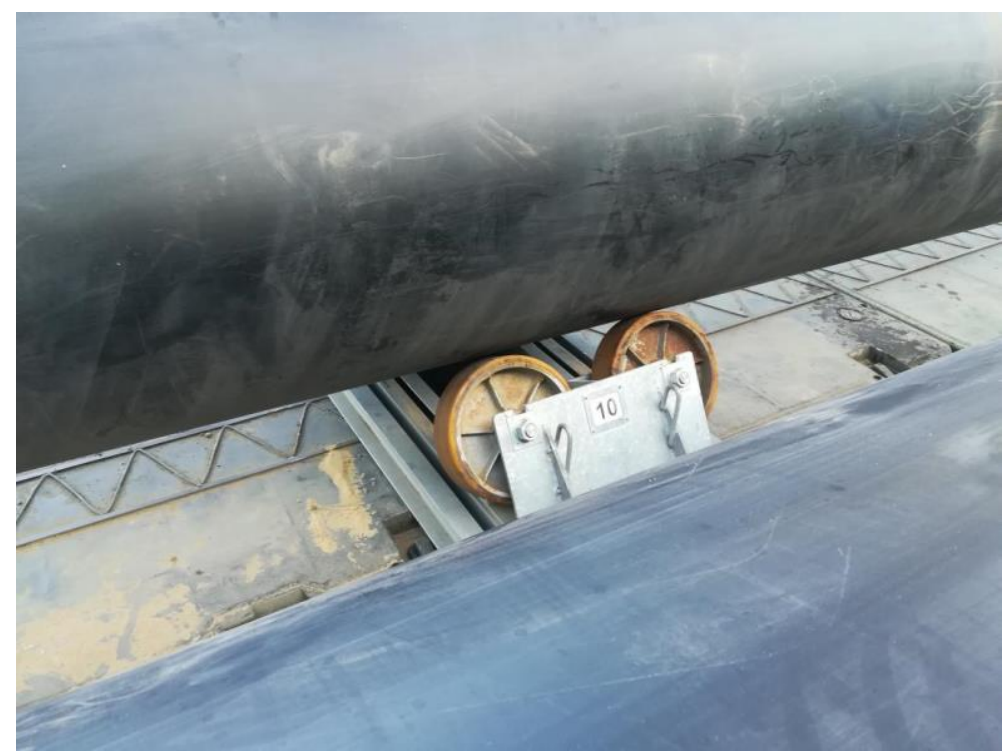

Fig. 7. Rollers for laying the pipelines on the bridge [own photograph].

Once the pipelines were laid along the bridge (Fig. 8), appropriate supports were put in place on each individual pontoon (timber board wedging) (Fig. 9). Fig. 10 depicts the pipelines laid along the entire bridge. 


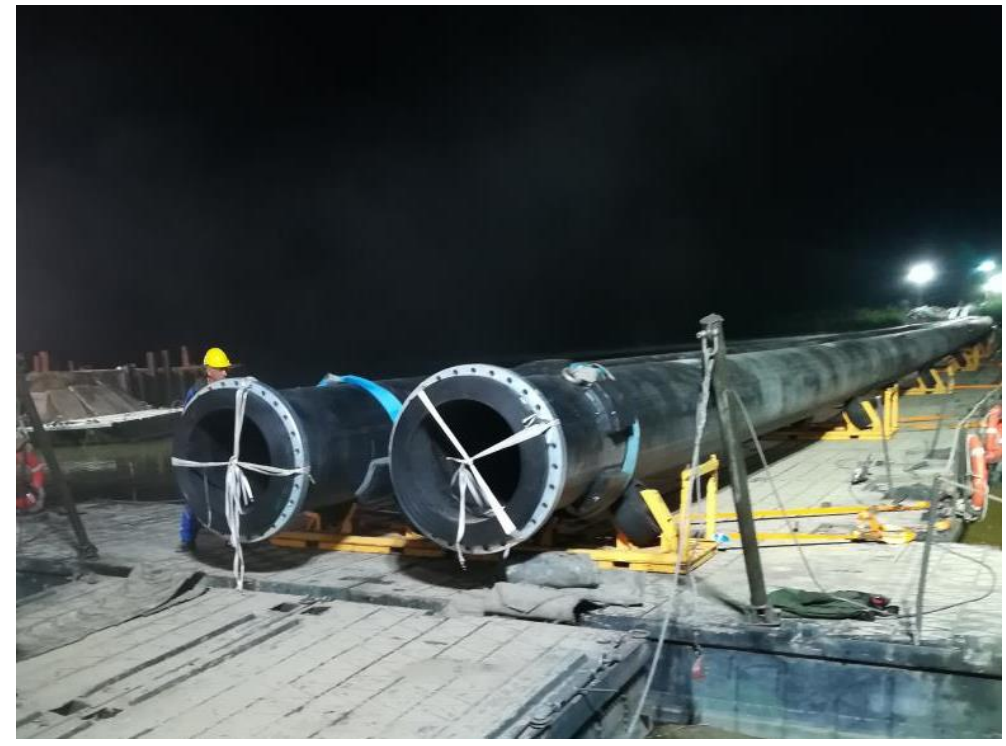

Fig. 8. Joined pipelines [own photograph].

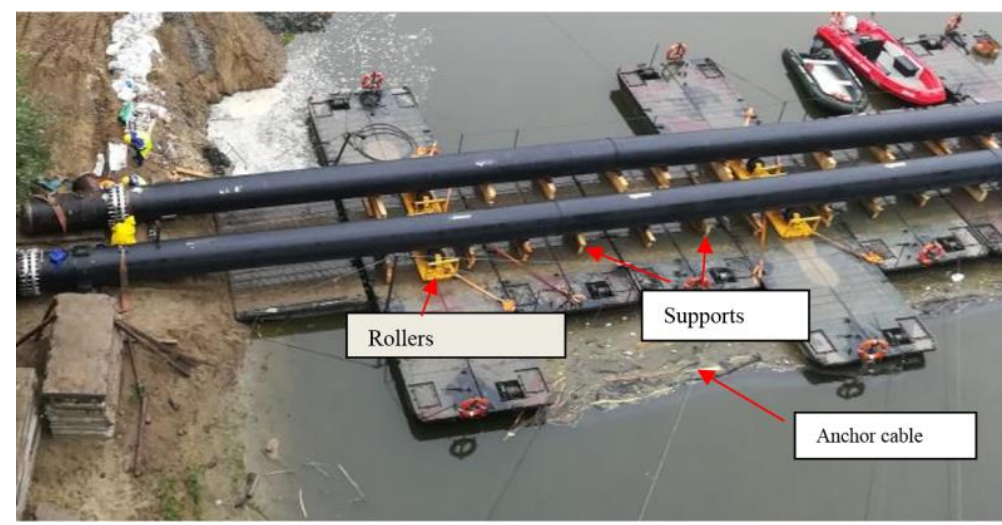

Fig. 9. Pipelines laid on rollers and supports [own photograph].

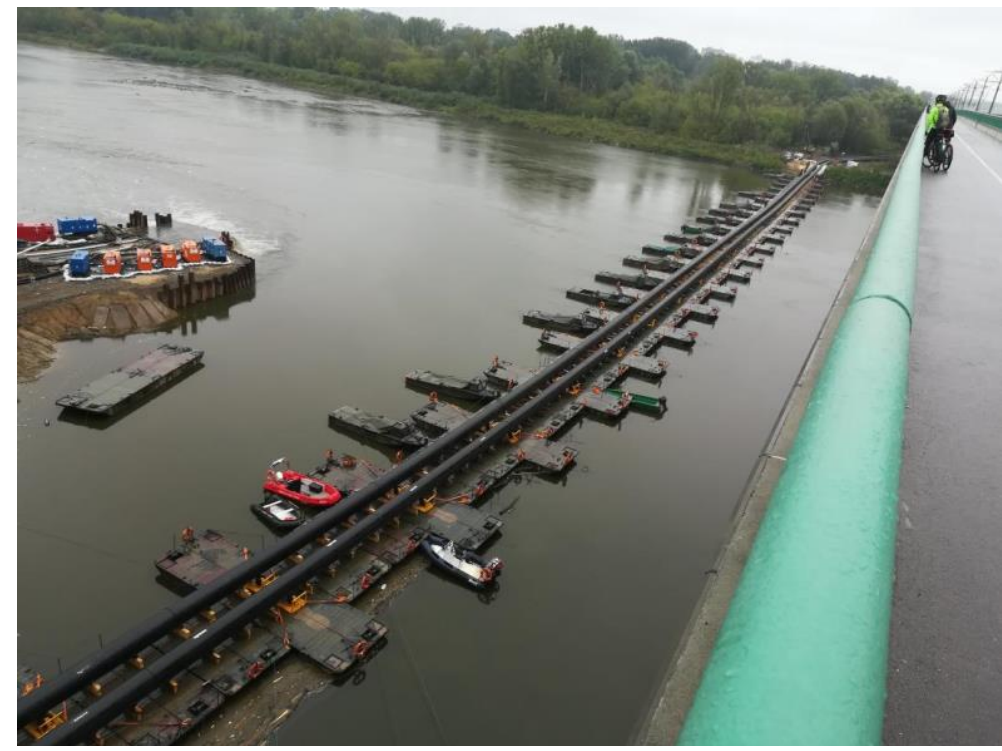

Fig. 10. View of both pipelines laid along the entire bridge [own photograph]. 


\subsection{Connecting the pipelines}

Once the pipelines had been laid along the bridge, steel inlet pipes were connected to the pumps. Two pipelines transporting wastewater from the discharge site were connected to each pipeline on the bridge (Fig. 11).

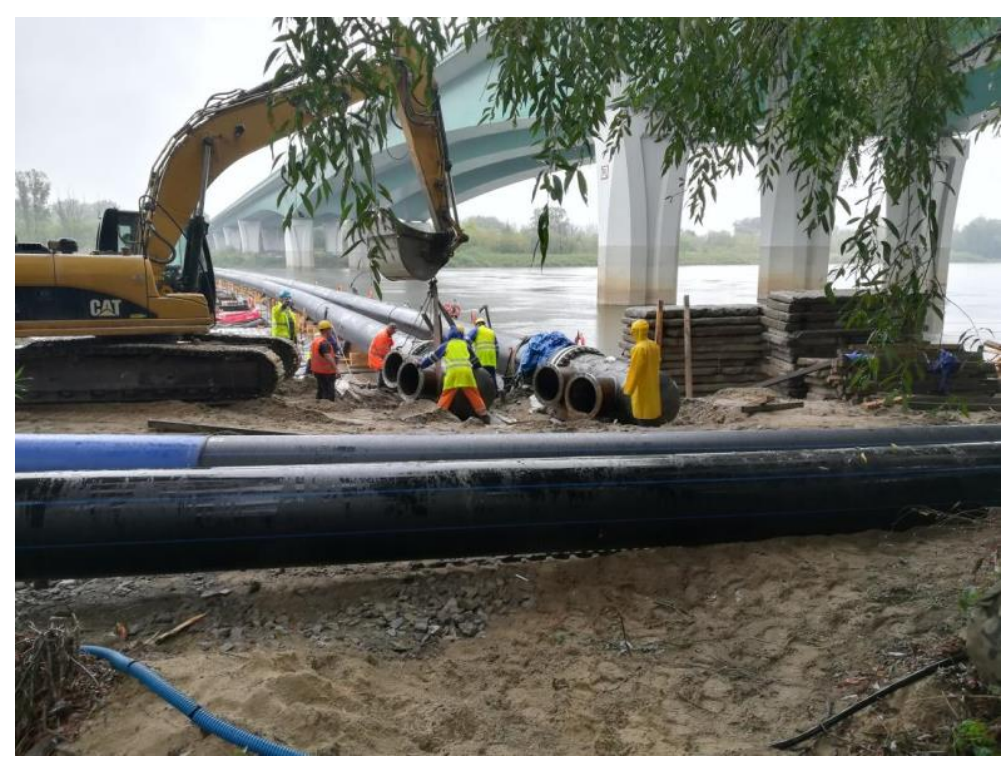

Fig. 11. Works on connecting inlet pipes to the pipelines on the bridge [own photograph].

Pipelines transporting sewage from the discharge site were connected directly to a bank of pumps (Fig. 12).

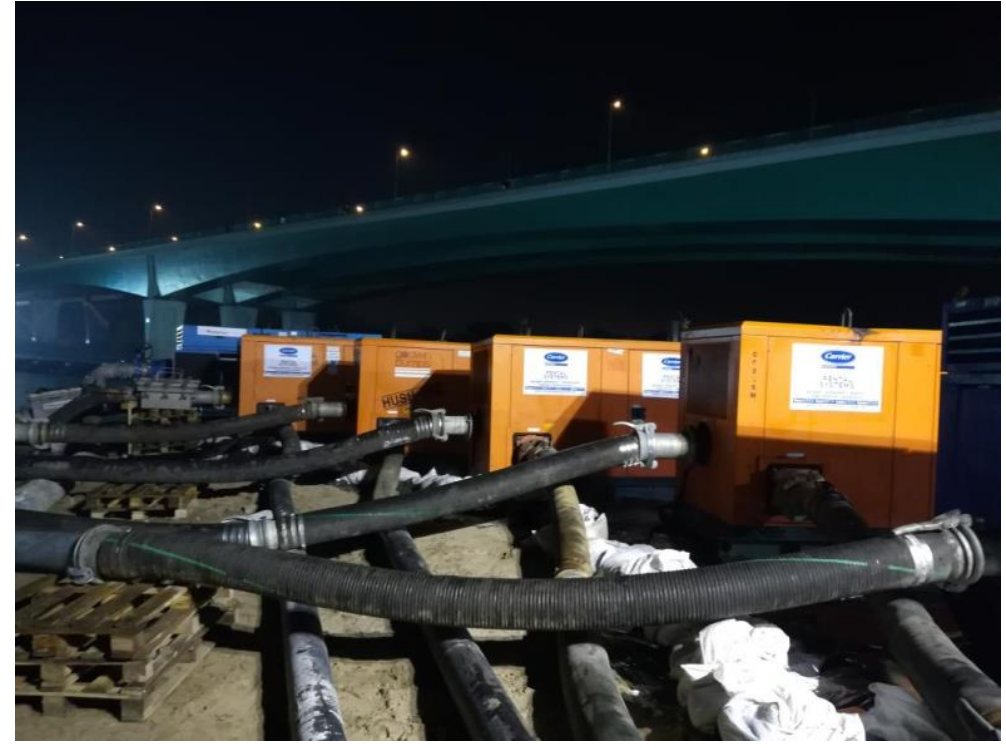

Fig. 12. Wastewater feed pumps at discharge site [own photograph].

\section{Using the crossing}

\subsection{Bridge operation under working load}

Once the pipelines had been laid on the bridge, a permanent load comprising their weight was transferred to the bridge (double units) through rollers (Fig. 13). This constituted $33 \%$ of the working load calculated for the pipelines under full load. The average draught of the bridge increased by 
approximately $15 \mathrm{~cm}$ to approximately $45 \mathrm{~cm}$ under its own weight plus that of the pipelines (see Fig. $14)$.

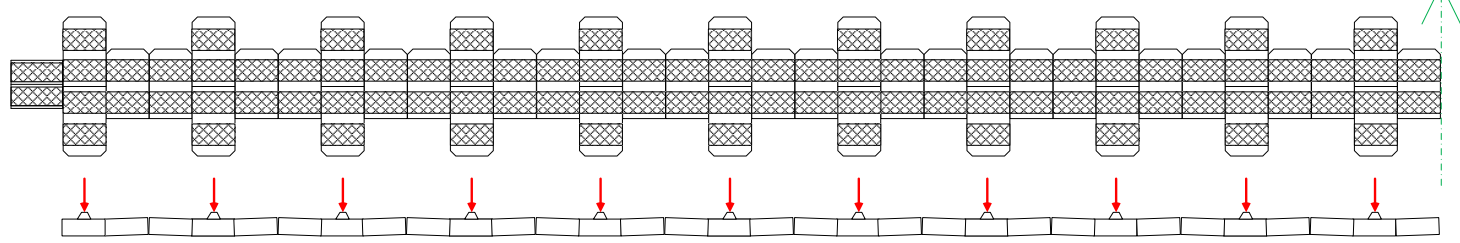

Fig. 13. Diagram depicting the load on the bridge exerted by the pipelines on rollers; red arrows represent loads transferred from the pipeline to the rollers.

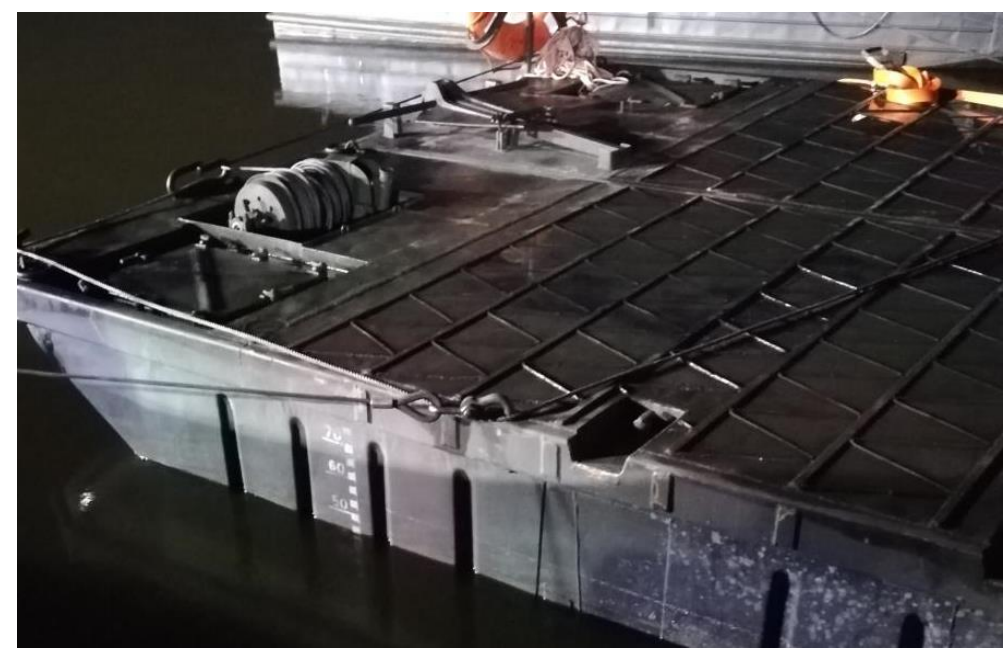

Fig. 14. Bridge draught under pipeline load [own photograph]

Prior to pumping sewage, as advised by the military representatives, wooden supports were placed under each pipeline (two per pontoon unit, approximately $1.85 \mathrm{~m}$ apart). The supports are depicted on the photograph below (Fig. 15). The support method was recommended in order to distribute the load more evenly across all the components (pontoons) so as to reduce load on the joints.
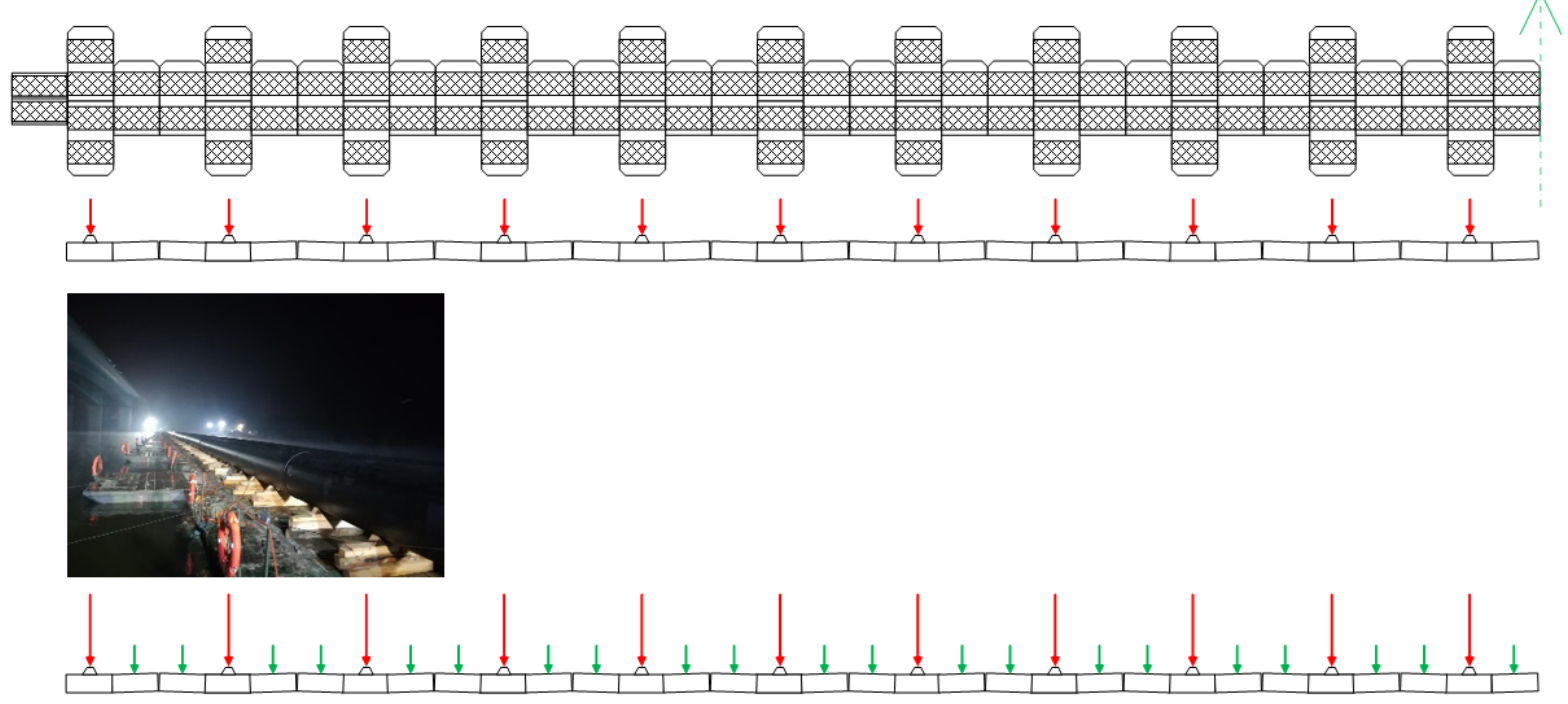

Fig. 15. View of the pipelines laid on supports; red arrows represent loads transferred from the pipelines to the rollers, while green arrows represent loads transferred by the additional wooden supports. 
When full, the pipelines constituted $67 \%$ of the overall working load. The average draught of the bridge increased by $0.2 \mathrm{~m}$. The total draught was about $65 \mathrm{~cm}$; the acceptable draught for this bridge was determined to be $0.8 \mathrm{~m}$ [1]. This maintains a draught reserve of $0.15 \mathrm{~m}$ and a freeboard reserve of about $0.3 \mathrm{~m}$. A view of the crossing under full load is shown in Fig. 16.

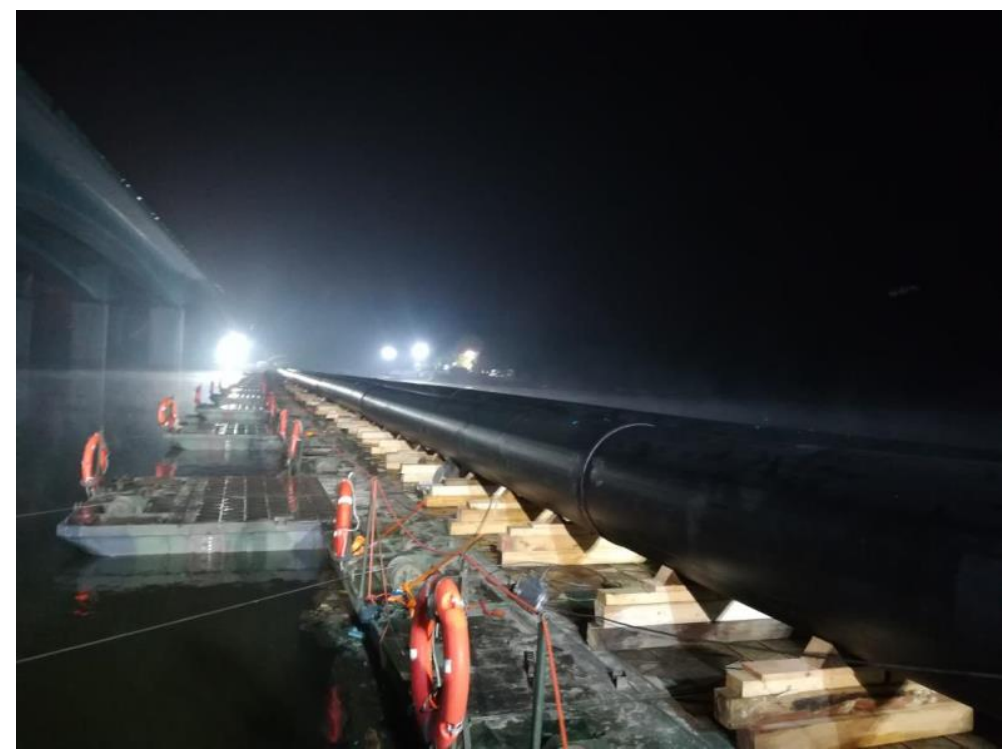

Fig. 16. The bridge under load exerted by two full pipelines [own photograph].

\subsection{Crossing maintenance}

To ensure safe use of the type C lane PP-64 pontoon bridge system, loaded with two wastewater pipelines, it was necessary to define safe operating conditions [8] - these were determined together with the pipeline contractor:

a) use of the bridge is possible subject to river current speed not exceeding $2.0 \mathrm{~m} / \mathrm{s}$, therefore at current speed of $1.8 \mathrm{~m} / \mathrm{s}$ the wastewater transfer must be stopped and when current speed of $2.0 \mathrm{~m} / \mathrm{s}$ is reached, it is absolutely necessary to disconnect the pipeline and separate the bridge into six sections;

b) bridge operation staff shall not remain on the facility while the pipelines are under pressure;

c) after the pipelines have been fully filled for the first time, stop pumping and reduce wastewater pressure in the pipelines to the minimum to allow adjustment of the anchor cables (start adjusting the cables upon a signal from the pump operator);

d) anchor cable adjustments shall be carried out with each river water level change of $0.2 \mathrm{~m}-$ for each adjustment, stop pumping and reduce wastewater pressure in the pipelines to the minimum (start adjusting the cables upon a signal from the pump operator);

e) tension of the anchor cables must be checked at least twice a day as part of operation - for each check, stop pumping and reduce wastewater pressure in the pipelines to the minimum (start adjusting the cables upon a signal from the pump operator);

f) once a day, the pipeline operation staff should provide the crossing service staff with data on the river water level, river current speed and changes in the pressure of wastewater in the pipeline;

g) during crossing maintenance works, pipeline operation staff are to wear life jackets.

Ensuring that the current speed does not exceed the determined value for the crossing $(2.0 \mathrm{~m} / \mathrm{s})$ was important. Table 1 below depicts a comparison of average current speed $\mathrm{V}_{\mathrm{av}}$ and flow magnitude $\mathrm{Q}$ for different water levels on the Vistula River. The figures obtained from "Wody Polskie" apply to a river cross section of 60 meters downstream from Most Północny (The Maria Skłodowska-Curie Bridge). 
Table 1. A comparison of average current speed $\mathrm{V}_{\mathrm{av}}$ and flow magnitude $\mathrm{Q}$ for different water levels on the Vistula River.

\begin{tabular}{|c|c|c|c|}
\hline River water level & $\mathrm{Q}\left[\mathrm{m}^{3} / \mathrm{s}\right]$ & $\mathrm{V}_{\mathrm{av}}[\mathrm{m} / \mathrm{s}]$ & $\mathrm{Z}[\mathrm{m}$ a.s.1.] \\
\hline NNQ & 147 & 0.35 & 73.80 \\
\hline SNQ & 229 & 0.49 & 74.08 \\
\hline SSQ & 568 & 0.86 & 75.08 \\
\hline SWQ & 2640 & 1.83 & 78.15 \\
\hline WWQ & 5940 & 1.65 & 80.95 \\
\hline
\end{tabular}

Whilst the bridge was in use in 2019, there was no need to disconnect the crossing (this would require the pipeline to be dismantled and then assembled once again) due to changes in the water level. However, such a situation did come to pass during a breakdown in 2020, when the crossing had to be dismantled on account of high water.

\section{Summary and conclusions}

The article presents an unusual use of a military floating bridge as a crossing for provisional pipelines transporting wastewater following a breakdown of the actual transport system. This meant wastewater was transported to the treatment plant, rather than discharged into the Vistula River. The pipelines were in use between 14 September and 16 November 2019 and carried more than 15 million cubic metres of wastewater which otherwise would have polluted the river.

Effective cooperation between army engineering units assigned to build the crossing and the pipeline contractor contributed to a tangible reduction in environmental pollution. For more than two months, the crossing facilitated the operation of a temporary system transferring sewage from leftbank Warsaw to the 'Czajka' treatment plant located on the right-bank of the Vistula River. Two parallel pipelines were laid on the pontoon bridge across a water obstacle. Without the crossing, it would not have been possible to construct the pipeline.

The adopted structural and technical solutions put into practice for the first time in 2019 were used once again in 2020 when the wastewater transport system suffered a second breakdown. The over 50 year old pontoon system proved its worth in an emergency situation under an abnormal work load. At the moment, efforts are underway to replace the current system with modern solutions [7], including analyses of using new materials [6,7].

\section{Bibliography}

[1] Bing Wang, Qi Sun, Ju-Xuan Li, Bo Yang and Chen Peng (2016) Study on the dynamic response of the floating bridge subjected to a single moving load, Material Engineering and Mechanical Engineering, pp. 835-843. https://doi.org/10.1142/9789814759687_0094

[2] Bursztynowski Z., Mosty pływające na oddzielnych podporach. WAT, Warszawa, 1988.

[3] Chłus K., Derewońko A., Krasoń W. (2013) Experimental and numerical verification of the pontoon bridge section, Journal of KONES Powertrain and Transport, Vol. 20, No. 1.

[4] Chmielewski R., Ocena techniczna. Sprawdzenie nośności typowej konstrukcji mostu pływającego z parku PP-64, wstęga typu C, pod obciążenie dwoma rurociągami odprowadzającymi ścieki. Praca niepublikowana, WAT, Warszawa, 2019.

[5] Gruszczyk A. (2006) Wykorzystanie parku PP-64 jako podpór dla konstrukcji wsporczej tymczasowego rurociągu, Praca magisterska (kierownik pracy: dr inż. Paweł Bryda), WAT.

[6] Kamyk Z., Śliwiński C. (2016) Impact of life cycle cost analysis on the pontoon bridge concept selection, Szybkobieżne Pojazdy Gąsienicowe (40) nr 2.

[7] Krasoń W., Bogusz P., Poplawski A., Stankiewicz M. (2019) Selected Aspects of Stand Tests for Prototype Floating, Materials Research Proceedings 12, pp. 90-95, https://doi.org/10.21741/9781644900215-13. 
[8] Kranz P., Instrukcja do utrzymania przeprawy z parku PP-64, wstęga typu C, pod obciążenie dwoma rurociągami odprowadzającymi ścieki. Warszawa, 2019.

[9] Park pontonowy PP-64. Opis i użytkowanie, Szefostwo Wojsk Inżynieryjnych MON, Warszawa, 1985. 